\title{
bp Andrzej F. Dziuba \\ Tylko Bóg. Z nauczania pasterskiego Wydawnictwo Naukowe Uniwersytetu Kardynała Stefana Wyszyńskiego, Warszawa 2018, ss. 332
}

Chrystus swoje wezwanie-posłannictwo: „Idźcie i nauczajcie wszystkie narody..." (Mt 28,19), skierował najpierw do Apostołów. Dzisiaj adresatami tego posłania są przede wszystkim następcy Apostołów - Biskupi, sprawujący pasterską opiekę nad Bożym Ludem. Realizacja ewangelizacyjnego posłannictwa biskupów posiada szereg form praktycznych. W każdym spotkaniu „z drugim” człowiekiem biskup jest świadkiem Chrystusa - Jego posłańcem. Taką postawę prezentuje bp Andrzej F. Dziuba - Ordynariusz Diecezji Łowickiej. Jego apostolska aktywność wyraża się też w działalności naukowo-badawczej. Jest to prof. zw. dr hab., długoletni i bardzo znany w Polsce i poza jej granicami profesor uniwersytecki, najpierw KUL w Lublinie, obecnie UKSW w Warszawie, gdzie jest kierownikiem Katedry Historii Teologii Moralnej na Wydziale Teologicznym tej uczelni. Znany jest i rozpoznawany jako aktywny uczestnik wielu konferencji naukowo-badawczych krajowych i zagranicznych. Potwierdzeniem jego aktywności naukowej jako biskupa są funkcje pełnione w ramach Episkopatu Polski: Przewodniczący Rady Naukowej KEP, delegat KEP na Międzynarodowe Kongresy Eucharystyczne, przewodniczący Zespołu ds. Szkolnictwa Wyższego. W tym zakresie swej działalności jest znany nie tylko w Polsce, czego wyrazem jest przyznany mu doktorat honoris causa the Polish University Abroad. 
Wyrazem apostolskiej aktywności ks. bp. prof. Andrzeja F. Dziuby jest jego książka Tylko Bóg. $Z$ nauczania pasterskiego. Jej treść stanowi 56 homilii - kazań wygłoszonych w latach 2015-2016. Są one potwierdzeniem zaangażowania Biskupa - pasterza diecezji łowickiej w liczne uroczyste wydarzenia tego Kościoła lokalnego. Jak zaznacza autor w Stowie wstępnym:

Są one bardzo różnorodne w swej treści, okolicznościach, adresatach i miejscach wygłoszenia. Zawsze jednak jest w nich podejmowane pełnienie posługi pasterskiej na drodze nowej ewangelizacji, do której tak mocno zachęcał św. Jan Paweł II (s. 13).

Ta „różnorodność” homilii ukazuje aktywność Biskupa diecezji łowickiej, który jest wszędzie tam, gdzie świętowane są ważne wydarzenia danej lokalnej wspólnoty. Jego obecność jako Pasterza, celebrowane Msze św. i wygłoszone homilie potwierdzają też potrzebę nadania tym wydarzeniom charakteru religijnego. W ten sposób utwierdza $\mathrm{w}$ wiernych i uaktywnia łączenie życia społecznego z religijną wiarą jako formą kultury będącą „,sposobem istnienia i bytowania człowieka” [Jan Paweł II].

Różnorodność adresatów zawartych w tej książce homilii można podzielić na pojedyncze osoby i wspólnoty. Wśród osób pojedynczych jest homilia podczas Mszy św. z okazji 35. rocznicy sakry biskupiej ks. abpa W. Ziółka - „Soli Deo w mocach Ducha” [s. 78-84]. Inne homilie wygłoszone zostały z okazji świętowania wspólnotowego kapłaństwa i życia zakonnego i konsekrowanego, rodzin i obrony życia poczętego, kobiet, młodzieży, osób niewidomych, katechetów i nauczycieli, osób życia pustelniczego. Najwięcej homilii było wygłoszonych z okazji uroczystości i świąt ogólnokościelnych i ogólnopolskich oraz diecezjalnych - zwłaszcza diecezji łowickiej. Ksiądz bp A. F. Dziuba był zapraszany z kazaniem na wiele uroczystości poza swoja diecezją, np. w Warszawie, Kaliszu, Gnieźnie, Jasnej Górze. Na podkreślenie zasługuje fakt, że w latach 2015-2016 Kościół przeżywał Rok Bożego Miłosierdzia. W tej

Reports and reviews książce umieszczona jest homilia wygłoszona przez bp. A. F. Dziubę 13 grudnia 2015 roku podczas otwarcia Bramy Miłosierdzia w bazylice katedralnej w Łowiczu [„,Bóg jest bogaty w Miłosierdzie”, s.158-164] oraz jej zamknięcie [„,Nadzieja zwycięstwa dobra w Chrystusie”, s. 316321]. Innym ważnym wydarzeniem tego czasu w diecezji łowickiej było nawiedzenie kopii obrazu Matki Bożej w Jasnogórskim Wizerunku, czemu poświęcone jest kilka homilii wygłoszonych przez bp. A. F. Dziubę w parafiach swej diecezji. Należy też podkreślić inne wydarzenie ogólnodiecezjalne, jakim było nawiedzenie przez symbole Światowych Dni Młodzieży; temu wydarzeniu poświęconych jest też kilka homilii 
bp. A. F. Dziuby. Ważnym wydarzeniem tego okresu dla wszystkich Polaków była 1050 rocznica Chrztu Polski. W diecezji łowickiej było to szczególnie przeżywane w Tumie koło Łęczycy [,,Święty Aleksy drogą sprawiedliwą i prostą", s. 241-246].

Kazania ks. bp. Andrzeja F. Dziuby są bardzo bogate treściowo i formalnie. Przede wszystkim należy podkreślić, że każde z nich jest wypowiedzią „,na temat”, co nie zawsze spotykamy w homiliach wielu autorów. Recenzowana książka zawiera kazania stanowiące wzorcowy przykład ewangelicznego przekazu treści. Poszczególne tematy są precyzyjnie sformułowane i rozwinięte, ubogacone odwołaniem się do konkretnych problemów, którym nadana została bogata interpretacja. Czytelnik tej książki uzyskuje bogatą wiedzę na różne zagadnienia religijno-moralne, społeczno-kulturowe i historyczno-organizacyjne odnoszące się do Kościoła powszechnego i lokalnego oraz bardziej konkretnych wydarzeń osobistych i społecznych. Lektura tych kazań ubogaca nie tylko wiedzę na podejmowane tematy, ale też sposobu interpretacji poszczególnych wydarzeń i powiązanych z tym zagadnień. Jest to niezwykle ważne i znaczące w kontekście współczesnych zawirowań poznawczo-interpretacyjnych, co spotykamy też w niektórych wypowiedziach ,z ambony”.

Tematyczna różnorodność i liczbowa wielość tematyki kazań ks. bp. A. F. Dziuby stanowi też piękne świadectwo pasterskiego zaangażowania łowickiego Biskupa, który towarzyszy poszczególnym osobom i wspólnotom w religijnym przeżywaniu danych wydarzeń. Zawarte w omawianej książce homilie ukazują ewangeliczno-eklezjalne widzenie tych faktów, umożliwiając poprawność ich kwalifikowania i przeżywania. Na podkreślenie zasługuje też fakt, że każde kazanie ks. bp A. F. Dziuba rozpoczyna pozdrowieniem skierowanym do konkretnych osób, szczególnie ważnych i znaczących w danej wspólnocie. Jest to świadectwo personalistyczno-przyjacielskiej postawy łowickiego Biskupa, który potrafi dostrzec i wyróżnić osoby na to zasługujące. Taka postawa jednoczy daną społeczność i mobilizuje do podobnych postaw w życiu każdego człowieka.

Lektura niniejszej książki utwierdza w przekonaniu, że homilie ks. bp. Andrzeja F. Dziuby stanowią dobry „podręcznik” dla każdego kaznodziei. Pomagają bowiem poprawnie sformułować treść i zakres kazania poświęconego konkretnemu zagadnieniu. Tytuł książki Tylko Bóg ukazuje cel wszelkich homilii i kazań oraz motywację tych wystąpień pasterskich. Jest też świadectwem celowości i motywacji pasterskiej posługi łowickiego Biskupa. 